\title{
1 A global assessment of freshwater fish introductions in mediterranean-climate regions
}

\section{Sean M. Marr • Julian D. Olden · Fabien Leprieur • Ivan Arismendi • Marko Ćaleta • David L. Morgan •} Annamaria Nocita $\cdot$ Radek Šanda $\cdot$ A. Serhan Tarkan $\cdot$ Emili García-Berthou

\section{S. M. Marr $(\bowtie)$}

Freshwater Research Unit, Zoology Department, University of Cape Town, Private Bag X3, Rondebosch, 7700,

South Africa. E-mail: erubescens@ gmail.com; telephone: +27 843682537

\section{J. D. Olden}

School of Aquatic and Fishery Sciences, University of Washington, Box 355020, Seattle, WA 98195-5020, USA

\section{F. Leprieur}

Laboratoire Ecologie des Systèmes Marins Côtiers UMR 5119, CNRS, IRD, IFREMER, UM2, UM1, cc 093, Place E. Bataillon, 34095 Montpellier Cedex 5, France

\section{Arismendi}

Department of Fisheries and Wildlife, Oregon State University, Nash Hall, Room \#104, Corvallis OR 973315503, USA

\section{M. Ćaleta}

Faculty of Teacher Education, University of Zagreb, Savska cesta 77, 10000 Zagreb, Croatia.

\section{L. Morgan}

Freshwater Fish Group \& Fish Health Unit, School of Veterinary and Life Sciences, Murdoch University, South Street, Murdoch, WA 6150, Australia

\section{A Nocita}

Museo di Storia Naturale, Università degli Studi di Firenze, Via Romana 17 - 50125 Firenze, Italy

\section{R. Šanda}

National Museum, Department of Zoology, Václavské náměstí 68, 11579 Praha, Czech Republic

\section{A. S. Tarkan}

Faculty of Fisheries, Muğla Sitkı Koçman University, 48000 Kötekli, Muğla, Turkey.

\section{E. García-Berthou}

Institute of Aquatic Ecology, University of Girona, E-17071, Girona, Spain 
40 Abstract Mediterranean-climate regions (med-regions) are global hotspots of endemism facing mounting

41 environmental threats associated with human-related activities, including the ecological impacts associated with

42 non-native species introductions. We review freshwater fish introductions across med-regions to evaluate the

43 influences of non-native fishes on the biogeography of taxonomic and functional diversity. Our synthesis

44 revealed that 136 freshwater fish species (26 families, 13 orders) have been introduced into med-regions

45 globally. These introductions, and local extirpations, have increased taxonomic and functional faunal similarity

46 among regions by an average of 7.5\% (4.6-11.4\%; Jaccard) and 7.2\% (1.4-14.0\%; Bray-Curtis), respectively.

47 Faunal homogenization was highest in Chile and the western Med Basin, whereas sw Cape and the Aegean Sea

48 drainages showed slight differentiation (decrease in faunal similarity) over time. At present, fish faunas of

49 different med-regions have widespread species in common (e.g. Gambusia holbrooki, Cyprinus carpio,

50 Oncorhynchus mykiss, Carassius auratus, and Micropterus salmoides) which are typically large-bodied, non-

51 migratory, have higher physiological tolerance, and display fast population growth rates. Our findings suggest

52 that intentional and accidental introductions of freshwater fish have dissolved dispersal barriers and significantly

53 changed the present-day biogeography of med-regions across the globe. Conservation challenges in med-regions

54 include understanding the ecosystem consequences of non-native species at macro-ecological scales.

55

56 Keywords Introduced species $\cdot$ non-native species $\bullet$ conservation biogeography $\bullet$ taxonomic homogenization $•$

57 functional homogenization

58 
Mediterranean-climate regions (med-regions) are recognised hotspots of biodiversity and endemism (Cowling et al., 1996). Concurrently, they are among the most densely human-populated regions because of their favourable climates that support valuable agricultural produce (e.g., fruit, winter wheat, and wine). Human enterprise in these regions has resulted in extensive habitat alteration, water pollution, high levels of water extraction and regulation, and the intentional and accidental introduction of many non-native species (Di Castri, 1991). As a result, freshwater ecosystems in med-regions are highly modified and continue to face mounting pressure from growing human populations and water development schemes (Economidis, 1995; Collares-Pereira et al., 2000; Millennium Ecosystem Assessment, 2005; Shumka et al., 2010). Unfortunately, aquatic faunas in these regions are considered to be experiencing among the fastest rates of species imperilment globally (Moyle, 1995).

Freshwater ecosystems are particularly affected by non-native species introductions, which produce a range of ecological and economic impacts (Cambray, 2003; Cucherousset \& Olden, 2011; García-Berthou \& Moyle, 2011). For instance, the zebra mussel Dreissena polymorpha and the Asian clam Corbicula fluminea act as ecosystem engineers and have caused significant economic impacts in North America and Europe by clogging water intake structures. Crayfishes have been introduced worldwide, such as the red swamp crayfish Procambarus clarkii that often reaches high abundance in Mediterranean waters and these introductions have contributed to the decline of native species (e.g., Gherardi \& Acquistapace, 2007). Riparian or aquatic plants such as the water hyacinth Eichhornia crassipes, Eurasian watermilfoil Myriophyllum spicatum, hydrilla Hydrilla verticillata, the ferns Salvinia molesta and Azolla filiculoides, and the giant reed Arundo donax, and insects, such as the black locust Robinia pseudoacacia, are global invaders that have profound effects on ecosystem structure and functioning (Brunel et al., 2010).

Our review focuses on spatial patterns and temporal trends in freshwater fish introductions in medregions. These regions are hotspots both of endemisms and freshwater fish introductions (Leprieur et al., 2008; Tedesco et al. 2012) and med-region aquatic habitats are severely threatened, in part, because of water scarcity and environmental degradation (Hermoso \& Clavero, 2011; Hermoso et al., 2011). Thus, we require a greater understanding of the impacts in these regions to guide management and policy actions. We focus on fish because their native and introduced ranges are well documented across these regions. 
91 Europe's history of non-native fish introductions dates back to the Roman Empire, through the progression of fish culturing in Medieval monasteries and parishes and by the nobility in the Renaissance to the $19^{\text {th }}$ century "Acclimation Societies" that provided incentives for the establishment (acclimation) of non-native plants and animals and the government-sanctioned introductions of the mid- $20^{\text {th }}$ century (Copp et al., 2005). At present, numerous non-native fish from a variety of sources have been introduced across Mediterranean Europe for the biological control of aquatic plants and mosquitoes, aquaculture, to compensate for the decline in native fish stocks, and to create new and more diverse recreational fisheries (Cowx, 1997; Hermoso \& Clavero, 2011). Although government-sanctioned fish introductions have ceased in many countries, the illegal release of nonnative species by anglers and aquarists, including accidental releases from aquaculture facilities, has continued (Elvira \& Almodóvar, 2001; Rahel, 2004). world. Non-native species of California were predominantly introduced for recreational angling, commercial fisheries, and forage/bait fish, or intentionally through the ornamental fish trade (Moyle, 1976). Populations of native fish have continued to decline as a result of a suite of threats (Moyle et al., 2011), with some salmonid species now approaching extinction (Katz et al., 2012). In Chile, the creation of recreational fisheries was the primary reason for fish introductions prior to the 1980s (Basulto, 2003), whereas government-sponsored aquaculture has been the major driving force for fish introductions in recent decades (Iriarte et al., 2005; Arismendi et al., 2009). Chile is currently one of the world's largest producers of cultured salmonids, accounting for more than $73 \%$ of Chile's aquaculture production (Buschmann et al., 2009). Introduced salmonids dominate the total fish abundance and biomass in streams and lakes (Soto et al., 2006; Arismendi et al., 2009). For example, in southern Chile native fish are absent from $40 \%$ of the streams in which salmonids are now present (Soto et al., 2006). The rapid colonisation of South American streams by escapees from salmonid culture facilities has raised concerns regarding the impact of these escapees on the native fish assemblages (Soto et al., 2001; Arismendi et al., 2009; Garcia de Leaniz et al., 2010). introductions involved ornamental fish and food fish for sailors, followed by salmonids for recreational angling, and biological control agents for mosquitoes (de Moor \& Bruton, 1988; Morgan et al., 2004; Marr et al., 2012). 

al., 2004; Impson, 2007). Recent estimates suggest that more than $90 \%$ of the river habitat in the sw Cape of Africa is currently invaded by non-native fishes (Marr et al., 2012). As in other med-regions, the rivers in sw Australia and the sw Cape are subject to high levels of water abstraction, habitat degradation, eutrophication, salinization, fragmentation, and pollution (Morgan et al., 2003; Impson, 2007).

Despite some benefits (contribution to fishery production, recreational fishery, aquaculture development, mosquito control, and reduction of heavy algal blooms), fish introductions have been associated with significant negative ecological and socio-economic impacts. The ecological impacts are manifested at: genetic (gene transcription, hybridisation); individual (behaviour, morphology, vital rates); population (transmission of parasites/diseases, demographic effects, distributional effects); community (species extirpations, compositional changes, alterations in food webs); and ecosystem (biochemical cycles, energy fluxes between ecosystems, ecological engineering) levels (Cucherousset \& Olden, 2011). Phylogenetic history and human affiliation have been identified as predictors favouring species of freshwater fish selected for introduction in med-regions (Alcaraz et al., 2005; Marr et al., 2010). Certain fish families are represented by disproportionally higher numbers of non-native species because of strong human biases towards introducing species, such as game fish, forage fish, and bio-control agents for aquatic weeds or mosquitoes (Clavero \& García-Berthou, 2006; GarcíaBerthou, 2007; Marr et al., 2010). The introduction of freshwater fishes has reduced the characteristic endemism of freshwater fish assemblages in med-regions regions (Marr et al., 2010) and the risk of further introductions remains extremely high because of increasing interest in angling, low public awareness about the impacts of non-native fish, and poor mechanisms to enforce bans on non-native fish introductions (Zenetos et al., 2009; Gozlan et al., 2010). species introductions have dramatically reshuffled the present-day biogeography of freshwater fishes (Leprieur et al., 2008). A growing pattern is emerging where the range expansion of ubiquitous non-native species and the

142 loss of endemic forms tend to be driving the homogenization of the species pools of fish faunas (i.e., decreasing beta-diversity) over time (Olden, 2006). Species introductions have caused shifts in fish community composition, including regional-scale biotic homogenization. It has been emphasised that the importance of identifying and understanding present-day patterns of biotic homogenization with the intention of establishing conservation goals aimed at reducing potential future ecological impacts (Olden, 2006). Although a number of biotic homogenization studies of freshwater fish assemblages have been completed, the majority have focused 
on taxonomic homogenization in temperate latitudes of the Northern Hemisphere. In contrast, comparative studies between different regions or over multiple scales are lacking (Olden et al., 2010; 2011), but see Velliger et al. (2011), Hermoso et al. (2012) and Vitule et al. (2012). A comparison of introductions across climatically similar regions promotes an understanding of invasion processes by isolating large-scale drivers other than regional climate (Pauchard et al., 2004), and focuses on the role of human activities (Jiménez et al., 2008) and the characteristics of the invading species (Moyle \& Marchetti, 2006). Comparative studies may also provide valuable information for the conservation of native species and the management of non-native species by establishing priority lists of potentially harmful species, evaluating the risk of homogenization of the invaded communities, developing guidelines for sustainable ecosystem management, and targeting dispersal pathways for the management of non-native species (Pauchard et al., 2004).

\section{Analysis of freshwater fish introductions}

Freshwater fish are among the most widely introduced vertebrate groups and will continue to be introduced even though their detrimental impacts have been well-documented (Lintermans, 2004; Cucherousset \& Olden, 2011). We conducted a global assessment of freshwater fish introductions across med-regions to compare the taxonomic and functional dimensions of biotic homogenization resulting from the introduction of non-native species and the extirpation of native species. We compiled data on freshwater bony fish (Osteichthyes) in medregions, excluding marine species that only occasionally enter freshwaters. We examined the northern Mediterranean Sea Basin (Med Basin) and four additional med-regions: California, central Chile, sw Australia, and the sw Cape of South Africa (Table 1). The Med Basin includes data from Portugal, Spain, France, Italy, Slovenia, Bosnia-Herzegovina, Montenegro, Croatia, Macedonia (Former Yugoslav Republic of Macedonia), Serbia, Albania, Greece, Bulgaria, and Turkey. Catchments from the southern and eastern Med Basin countries were not considered due to the paucity of reliable data available for these countries. A catchment-level database for freshwater fish presence-absence records was compiled from available literature (see Table S1 Supplemental Material for a list of sources) for 374 catchments within these regions: the Iberian Peninsula (35), France (20), Italy (36), the eastern Adriatic Coast (17), Greece (90), Turkey (40), California (32), Chile (13), sw Australia (33), and the sw Cape (48). For each catchment, we recorded the number of historical native (including extirpations), extirpated native, and non-native fishes. Non-native species were defined as species that did not 
historically occur in the area, but have subsequently established self-sustaining populations as a result of human activities and included translocations (i.e., species native to the region but not a particular catchment). The "historical" species assemblage for each region was reconstructed from the literature, whereas the "present" species assemblage was based on the most recent available data, taking into account recorded introductions and extirpations. For some analyses, the catchment-level data were aggregated to regional level using the biogeographic regions delineated by Abell et al. (2008).

A total of 136 species of fishes from 26 families in 13 orders have been recorded as introduced and established into the med-regions included in this study (Table 1). The Med Basin has received 88 species from 21 families and 10 orders while other med-regions received 68 species from 19 families in 10 orders. Some regions such as California or the Italian Peninsula currently have more species of introduced than of native origin. The most widely introduced fish are global invaders such as the eastern mosquitofish Gambusia holbrooki, common carp Cyprinus carpio, rainbow trout Oncorhynchus mykiss, goldfish Carassius auratus, and similar species generally from European or North American origin and introduced for sport fisheries or aquaculture (Table 2). Species translocation within regions has been more frequent in California (12 species) and the Cantabric coast-Languedoc region (10) but not recorded in numerous regions (Aegean Sea, Western, Southern, and Central Anatolia, Chile, and sw Australia drainages). Ten regions recorded regional extirpations (Table 1), particularly Central Anatolia (8 species) followed by California, Cantabric coast-Languedoc, and Southern Iberia (3 spp. each). California, Central Anatolia, and the South-eastern Adriatic Coast are the only regions with known global extirpations: Gila crassicauda and Pogonichthys ciscoides in California; Alburnus akili and Pseudophoxinus handlirschi in Central Anatolia; and Chondrostoma scodrense in the Southern Adriatic Coast.

The introduction of non-native fishes has resulted in the loss of faunal uniqueness of these regions while increasing the total number of fish species (see also Leprieur et al., 2008; Marr et al., 2010). The highest number of introduced species is found for California, followed by Peninsular Italy, the Gulf of Venice Drainages, and the Dalmatian Coast. The high number of non-native fishes found in Italy can be explained by the higher lack of control on freshwater fish introductions there (Copp et al., 2005; García-Berthou et al., 2005). Further, our results confirm that California is an invasion hotspot (e.g., freshwater fishes, Leprieur et al., 2008; plants, Jiménez et al., 2008). 
The analysis of taxonomic and geographical patterns of freshwater fish introductions highlights the role of human mediation in the selection of the species introduced into med-regions. Our analyses reveal that the majority of non-native fish species (121 out of 136) introduced in these regions belong to five taxonomic orders (Cypriniformes, Cyprinodontiformes, Perciformes, Salmoniformes, and Siluriformes), as noted in previous regional-scale studies in California (Moyle \& Marchetti, 2006), the Iberian Peninsula (Alcaraz et al., 2005), sw Australia (Morgan et al., 2004), and five med-regions (Marr et al., 2010). In this review, nine families of freshwater fish have been found to be non-randomly introduced (i.e., Cyprinidae, Salmonidae, Centrarchidae, Cichlidae, Gobiidae, Acipenseridae, Ictaluridae, Poeciliidae, and Percidae) accounting for $81 \%$ of the species established. Similarly, Kark \& Sol (2004) found that only six bird families represent more than $78 \%$ of introductions into the Med Basin and they were also non-randomly introduced. In addition, all the med-regions we examined currently contain orders or families not historically present. This is particularly noticeable in the Southern Hemisphere. Historically, Salmoniformes and Cyprinodontiformes were not present in any of the Southern Hemisphere's med-regions, while Cypriniformes were absent from sw Australia and Chile. Moreover, the families Centrarchidae and Cichlidae were never present in any of the med-regions of the Southern Hemisphere.

All nine families of freshwater fish have been introduced in med-regions because they are of interest to humans (see also Alcaraz et al., 2005). Salmoniformes of the family Salmonidae are important recreational angling and aquaculture species and they are significantly over-represented in most regions, with the exception of Anatolia, where non-native salmonids appear to be unable to establish self-sustaining populations (Çelikkale, 2002). Perciformes contain important recreational angling (e.g., Centrarchidae) and aquaculture (e.g., Cichlidae) species and were over-represented only in California and the sw Cape. The family Centrarchidae were overrepresented in the Med Basin west of the Aegean Sea, California, and the sw Cape, highlighting the importance of recreational fisheries in these regions.

By contrast, we found that Characiformes and Siluriformes were under-represented when all regions were considered together, but not for any specific region. Indeed, Siluriformes and Characiformes have large numbers of tropical species that may not be able to readily establish in med-regions, where environmental conditions may extend beyond their physiological tolerances (Marr et al., 2010). Cypriniformes is a large order which has not been introduced to the same extent as smaller families, such as Salmonidae, probably because of 
their low economic value as recreational and aquaculture human purposes. Overall, our results provide evidence that taxonomic preference and human association are important factors predicting successful freshwater fish introductions (see also Alcarazet al., 2005, Blanchet et al., 2010). origins. The diversity of geographical origins poses a challenge to conservation authorities to identify potential source regions of species that would successfully become established. A similar result was obtained for plants in central Chile and California (Jiménez et al., 2008). The diversity of origins highlights the importance of studies aimed at identifying characteristics of species that have successfully established self-sustaining populations in other regions.

Patterns of taxonomic homogenization

The analysis of taxonomic homogenization provides an indication of whether species assemblages in the respective med-regions are becoming more, or less, similar in taxonomic composition over time. Taxonomic homogenization of the freshwater fish faunas of the med-regions was calculated using presence absence data at both regional- and catchment-level; see Supplemental Material for detailed methods. Jaccard's index of similarity was selected for the taxonomic data because it is the most commonly used index in taxonomic homogenization studies (Olden \& Rooney, 2006); but Baiser et al. (2012) has discussed other appropriate indices for this type of analysis.

The average historical taxonomic similarity among native freshwater fish faunas of the northern Med Basin, calculated as the average of the pair-wise similarity, was $8.6 \%$, whereas that for the other med-regions was $0.1 \%$ (California 0\%; Chile 0.2\%; sw Australia 0.2\%; and sw Cape 0\%). Our results show strong evidence of on-going taxonomic homogenization in the fish faunas of the med-regions $(\sim 7.5 \%$ when considering all the studied regions: northern Med 7.8\%; California 5.5\%; Chile 7.7\%; sw Australia 6.5\%; and sw Cape 5.3\%). The level of taxonomic homogenization differs among regions (from 4.6 to $10.4 \%$, Table 1) and appears to be independent of the number of species historically native to the area. Taxonomic homogenization was highest in Med Basin regions west of the Adriatic Sea (Cantabric Coast > Vardar > Thrace > Gulf of Venice; Table 1). Multivariate ordination analysis (N-MDS) on Jaccard's similarity index among regions supports a strong overall tendency toward increasing similarity of fish fauna over time (Fig. 1a). Although present-day faunal 
assemblages remain more similar to their historical assemblages than to those of any other regions, regions have become considerably more similar in present times (PERMANOVA, $P<0.05$ ).

The catchment-level analysis shows taxonomic homogenization in all regions, with the exception of the sw Cape and the Aegean Sea drainages, which shows differentiation in more than $50 \%$ of their catchments (Fig. 2). Homogenization is highest in Chile and the western Med Basin. The overall change in regional multivariate dispersion of catchments (i.e., variability in species composition) between the historical and present-day assemblages is significant (PERMDISP, $P<0.05$ ), but mainly as a result of changes for Western Iberia, California, Chile and the sw Cape. The overall change in the position of the regional centroids between the historical and present-day catchments is significant for all regions (PERMANOVA, $P<0.05$ ) with the exception of the Med Basin east of the Ionian Sea.

This high level of taxonomic homogenization found at across med-regions can be explained by the widespread introduction of a common set of non-native fishes (e.g., G. holbrooki, C. carpio, O. mykiss, C. auratus, Micropterus salmoides, Lepomis gibbosus, Carassius gibelio, Salmo trutta, Lepomis macrochirus, Gambusia affinis, Pseudorasbora parva, and Oreochromis mossambicus). For instance, our results show that 10 species were introduced into five or more regions and that the above 12 species were introduced into more than $10 \%$ of the studied catchments.

Our results contrast with those found by Villéger et al. (2011), who showed that the current level of taxonomic homogenization for freshwater fishes was rather low $(0.5 \%)$, hence concluding that the "Homogocene era" is not yet the case for the freshwater fish fauna at the worldwide scale. However, Villéger et al. (2011) studied taxonomic homogenization across different climatic regions by quantifying the changes in similarity caused by non-native fishes introductions between tropical and temperate catchments. We indeed expect that catchments from different climatic regions are more likely to be colonised by different non-native species as result of environmental filtering (e.g., Lapointe \& Light, 2012), hence explaining the low level of taxonomic homogenization found by Villéger et al. (2011). Previous large-scale analyses of multiple climate regions support this perspective (Olden et al., 2008; Baiser et al., 2012). Overall, we concur with Pauchard et al. (2004) that analysing global-scale patterns of biotic homogenization across climatically similar regions allows a better understanding of biotic homogenization processes by isolating large-scale factors other than regional climate, e.g. by focusing on the role of human use of non-native species and the characteristics of the recipient pool of native species. 
Most biotic homogenization studies focus on changes in the taxonomic composition of faunas and floras (see

Olden et al., 2010), whereas changes in functional trait composition have received considerably less attention (but see Pool \& Olden, 2012). Yet, the functional component of biodiversity has been shown to explain ecosystem functioning better than classical taxonomic measures of diversity (see Hooper et al., 2005). We calculated functional homogenization of the freshwater fish faunas of the med-regions using presence-absence data (at regional- and catchment-levels) and functional trait data compiled from FishBase (Froese \& Pauly, 2010) (see Supplemental Material for detailed methods). The Bray-Curtis similarity coefficient was used to evaluate the functional homogenization between the regions/catchments. Australia 68.2\%; and sw Cape 68.2\%). The functional composition of regional fish assemblages in med-regions has also changed over recent time (PERMANOVA, $P<0.005$ ); mean compositional similarity has increased between 1.2 and 14.0\% (mean 6.8\%: northern Med 6.7\%; California 2.6\%; Chile 9.7\%; sw Australia 9.7\%; and sw Cape 7.7\%, Table 2). Functional homogenization is highest in Peninsular Italy (14.0\%) and Central Anatolia (13.7\%) and lowest in the Aegean drainages (1.2\%) and California (2.6\%) (Table 1). The N-MDS analysis shows a strong overall tendency toward more functionally similar fish faunas (Fig. 1b). Six functional traits contributed to more than $60 \%$ of the increase in similarity of the faunal assemblages, each increasing in frequency by more than $5 \%$ between the historical and present-day assemblages. Current assemblages have more species with the following functional traits: being non-migratory, with a population doubling time between 1.4-4.4 years, invertivores, exhibiting no parental care, having moderate levels of tolerance, and with large body sizes (ranges of 40-160 cm) (Fig. 3).

All studied regions showed catchment-level functional homogenization in more than $50 \%$ of their catchments with the exception of Central Anatolia and the Aegean Sea drainages, which show differentiation (Fig. 2). Functional homogenization is highest in Chile, followed by Western Iberia and the Adriatic Sea drainages. The change between the historical and present-day assemblages is significant for all regions (PERMANOVA, $P<0.05$ ) with the exception of the Med Basin east of the southern Adriatic drainages. The changes in functional similarity are the result of the introduction of species with the traits highlighted in the regional-level analysis. Our catchment-scale analysis reveals changes in functional composition of fish 
assemblages for all regions as a result of non-native fish introductions and native species extirpations (circa $7 \%$ when considering all the studied regions). We also found that catchments exhibiting taxonomic homogenization are also homogenized in terms of their trait composition, a pattern also highlighted by Pool \& Olden (2012) in a finer spatial scale study.

Overall, our results are concordant with one of the general predictions of biotic homogenization: specialist species with limited ranges are being replaced by widespread generalist species (McKinney \& Lockwood, 1999; Clavel et al., 2010). Present-day assemblages across regions have more large-bodied species, display nonmigratory behaviour, exhibit faster population doubling times, and are characterized as invertivores, with no parental care (and presumable higher fecundity), and moderate levels of physiological tolerance. These shifts in the functional composition may have many subtle impacts on the recipient systems. For instance, the increase in large bodied and long lived species may result in the increased hold-up of nutrients in the freshwater system, which reduces transport of freshwater-derived nutrients to estuaries and inshore marine systems. With regards to body size, our results have important implications because there is increasing empirical evidence that changing the body size structure of assemblages affects ecosystem functioning (Long \& Morin, 2005; Woodward et al., 2005).

\section{Concluding remarks}

Overall, this study emphasizes that the introduction of non-native fish species has resulted in the loss of uniqueness of med-regions while increasing the total number of fish species. Specifically, our results suggest that the introduction of non-native fish species and the loss of native fish species affected the functional composition of freshwater fish assemblages, which may have important consequences for the functioning of freshwater ecosystems in such regions.

The extent of these alterations requires further attention by focusing on the interactive effects of nonnative fish introductions and habitat alteration. In many of the med-regions, the remaining native populations are restricted to ever decreasing river fragments that have not been invaded by non-native species or altered by unsustainable water consumption. We predict that the patterns of biotic homogenization seen in freshwater ecosystems of med-regions will intensify in the future unless these regions are recognised as highly valuable ecosystems for conservation and long-term sustainable management. 
Acknowledgements Author contributions: SMM developed the initial concept of the paper and analysed the data; SMM, JDO, FL, and EGB wrote the manuscript; all authors contributed data and revised the final version of the manuscript. SMM acknowledges the financial support of the DST/NRF Centre of Excellence for Invasion Biology and the David and Elaine Potter Foundation during his $\mathrm{PhD}$ studies. EGB acknowledges funding support from the Spanish Ministry of Science (projects CGL2009-12877-C02-01 and Consolider-Ingenio 2010 CSD2009-00065). DLM acknowledges Dr Stephen Beatty (Murdoch University) for his work on the fishes of south-western Australia. RŠ acknowledges support from the Czech Ministry of Culture (DKRVO2012 and DKRVO 2013/14, National Museum, 00023272). The authors thank Nicolas Poulet (ONEMA) for providing data on French Mediterranean river systems and Meta Povž for providing data on North Adriatic river systems.

\section{References}

Abell, R., M. L. Theime, C. Revenga, M. Bryer, M. Kottelat, N. Bogutskaya, B. Coad, N. Mandrak, S. Contreras-Balderas, W. Bussing, M. L. J. Stiassny, P. Skelton, G. R. Allen, P. Unmack, A. Naseka, R. Ng, N. Sindorf, J. Robertson, E. Armijo, J. V. Higgins, T. J. Heibel, E. Wikramanayake, D. Olson, H. L. Lopez, R. E. Reis, J. G. Lundberg, M. H. Sabaj Perez \& P. Petry, 2008. Freshwater Ecoregions of the world: a new map of biogeographic units for freshwater biodiversity conservation. BioScience 58:403414.

Alcaraz, C., A. Vila-Gispert \& E. García-Berthou, 2005. Profiling invasive fish species: the importance of phylogeny and human use. Diversity and Distributions 11:289-298.

Arismendi, I., D. Soto, B. Penaluna, C. Jara, C. Leal \& J. León-Muñoz, 2009. Aquaculture, non-native salmonid invasions and associated declines of native fishes in Northern Patagonian lakes. Freshwater Biology 54:1135-1147.

Baiser, B., J. D. Olden, S. Record, J. L. Lockwood \& M. L. McKinney., 2012. Pattern and process of biotic homogenization in the New Pangaea. Proceedings of the Royal Society B: Biological Sciences 279:47724777.

Basulto, S., 2003. El largo viaje de los salmones: Una crónica olvidada: propagación y cultivo de especies acuáticas en Chile. Editorial Maval, Santiago.

Blanchet, S., G. Grenouillet, O. Beauchard, P. A. Tedesco, F. Leprieur, H. H. Dürr, F. Busson, T. Oberdorff \& S. Brosse, 2010. Non-native species disrupt the worldwide patterns of freshwater fish body size: implications for Bergmann's rule. Ecology Letters 13:421-431. 
Brunel, S., G. Schrader, G. Brundu \& G. Fried, 2010. Emerging invasive alien plants for the Mediterranean Basin. EPPO Bulletin 40:219-238.

Buschmann, A. H., F. Cabello, K. Young, J. Carvajal, D. A. Varela \& L. Henriquez, 2009. Salmon aquaculture and coastal ecosystem health in Chile: analysis of regulations, environmental impacts and bioremediation systems. Ocean and Coastal Management 52:243-249.

Cambray, J. A., 2003. Impact on indigenous species biodiversity caused by the globalisation of alien recreational freshwater fishes. Hydrobiologia 500:217-230.

Çelikkale, M. S., 2002. İçsu Balıkları ve Yetiştiriciliği (Aquaculture of Freshwater Fish). Karadeniz Technical University Press, Trabzon.

Clavel, J., R. Julliard \& V. Devictor, 2010. Worldwide decline of specialist species: toward a global functional homogenization? Frontiers in Ecology and the Environment 9:222-228.

Clavero, M. \& E. García-Berthou, 2006. Homogenization dynamics and introduction routes of invasive freshwater fish in the Iberian Peninsula. Ecological Applications 16:2313-2324.

Collares-Pereira, M. J., I. G. Cowx, F. Ribeiro, J. A. Rodrigues \& L. Rogado, 2000. Threats imposed by water resource development schemes on the conservation of endangered fish species in the Guadiana River Basin in Portugal. Fisheries Management and Ecology 7:167-178.

Copp, G. H., P. G. Bianco, N. G. Bogutskaya, T. Erös, I. Falka, M. T. Ferreira, M. G. Fox, J. Freyhof, R. E. Gozlan, J. Grabowska, V. Kováč, A. R. Moreno-Amich, A. M. Naseka, M. Peňáz, M. Povž, M. Przybylski, M. Robillard, I. C. Russell, S. Statkens, S. Šumer, A. Vila-Gispert \& C. Wiesner, 2005. To be, or not to be, a non-native freshwater fish? Journal of Applied Ichthyology 21:242-262.

Cowling, R. M., P. W. Rundel, B. B. Lamont, M. K. Arroyo \& M. Arianoutsou, 1996. Plant diversity in Mediterranean-climate regions. TREE 11:362-366.

Cowx, I. G., 1997. Introduction of fish species into European fresh waters: economic successes or ecological disasters? Bulletin français de la pêche et de la pisciculture 344-345:57-78.

Cucherousset, J. \& J. D. Olden, 2011. Ecological impacts of non-native freshwater fishes. Fisheries 36:215-230.

de Moor, I. J. \& M. N. Bruton, 1988. Atlas of alien and translocated indigenous aquatic animals in Southern Africa. South African National Scientific Programmes Report No. 144. CSIR, Pretoria.

Di Castri, F., 1991. An ecological overview of the five regions with a Mediterranean climate. In Groves, R. H. \& F. Di Castri (eds), Biogeography of Mediterranean Invasions. Cambridge University Press, Cambridge: 3-16.

Economidis, P. S., 1995. Endangered freshwater fishes of Greece. Biological Conservation 72:201-211. 
Elvira, B. \& A. Almodóvar, 2001. Freshwater fish introductions in Spain: facts and figures at the beginning of the 21 st century. Journal of Fish Biology 59 (Supplement A):323-331.

Froese, R. \& D. Pauly (eds), 2010. FishBase 2010: concepts, design and data sources. International Center for Living Aquatic Resource Management, Manila. www.fishbase.org.

García-Berthou, E., 2007. The characteristics of invasive fishes: what has been learned so far? Journal of Fish Biology 71 (Supplement D):33-35.

García-Berthou, E., C. Alcaraz, Q. Pou-Rovira, L. Zamora, G. Coenders \& C. Feo, 2005. Introduction pathways and establishment rates of invasive aquatic species in Europe. Canadian Journal of Fisheries and Aquatic Sciences 62:453-463.

García-Berthou, E. \& P. B. Moyle, 2011. Rivers. In Simberloff, D. \& M. Rejmánek (eds), Encyclopedia of Biological Invasions. University of California Press, Berkeley \& Los Angeles: 609-612.

Garcia de Leaniz, C., G. Gajardo \& S. Consuegra, 2010. From best to pest: changing perspectives on the impact of exotic salmonids in the Southern Hemisphere. Systematics and Biodiversity 8:447-459.

Gherardi, F. \& P. Acquistapace, 2007. Invasive crayfish in Europe: the impact of Procambarus clarkii on the littoral community of a Mediterranean lake. Freshwater Biology 52:1249-1259.

Gozlan, R. E., J. R. Britton, I. G. Cowx \& G. H. Copp, 2010. Current knowledge on non-native freshwater fish introductions. Journal of Fish Biology 76:751-786.

Hermoso, V. \& M. Clavero, 2011. Threatening processes and conservation management of endemic freshwater fish in the Mediterranean basin: a review. Marine and Freshwater Research 62:244-254.

Hermoso, V., M. Clavero, F. Blanco-Garrido \& J. Prenda, 2011. Invasive species and habitat degradation in Iberian streams: an analysis of their role in freshwater fish diversity loss. Ecological Applications 21:175-188.

Hermoso, V., M. Clavero \& M. J. Kennard, 2012. Determinants of fine-scale homogenization and differentiation of native freshwater fish faunas in a Mediterranean Basin: implications for conservation. Diversity and Distributions 18:236-247.

Hooper, D. U., F. S. Chapin, J. J. Ewel, A. Hector, P. Inchausti, S. Lavorel, J. H. Lawton, D. M. Lodge, M. Loreau, S. Naeem, B. Schmid, H. Setälä, A. J. Symstad, J. Vandermeer \& D. A. Wardle, 2005. Effects of biodiversity on ecosystem functioning: a consensus of current knowledge. Ecological Monographs 75:335 .

Impson, N. D., 2007. Freshwater fishes. In Cape Nature (ed), Western Cape Province State of Biodiversity 2007. Cape Nature Scientific Services, Stellenbosch: 18-36. 
Iriarte, J. A., G. A. Lobos \& F. M. Jaksic, 2005. Invasive vertebrate species in Chile and their control and monitoring by government agencies. Revista Chilena de Historia Natural 78:143-154.

Jiménez, A., A. Pauchard, L. A. Cavieres, A. Marticorena \& R. O. Bustamante, 2008. Do climatically similar regions contain similar alien floras? A comparison between the Mediterranean areas of central Chile and California. Journal of Biogeography 35:614-624.

Kark, S. \& D. Sol, 2004. Establishment success across convergent Mediterranean ecosystems: an analysis of bird introductions. Conservation Biology 19:1519-1527.

Katz, J., P. B. Moyle, R. M. Quiñones, J. Israel \& S. Purdy, 2012. Impending extinction of salmon, steelhead, and trout (Salmonidae) in California. Environmental Biology of Fishes DOI 10.1007/s10641-012-9974-8.

Lapointe, N. W. R. \& T. Light, 2012. Landscape-scale determinants of non-native fish communities. Diversity and Distributions 18:282-293.

Leprieur, F., O. Beauchard, S. Blanchet, T. Oberdorff \& S. Brosse, 2008. Fish invasions in the world's river systems: when natural processes are blurred by human activities. PLoS Biology 6:e28.

Lintermans, M., 2004. Human-assisted dispersal of alien freshwater fish in Australia. New Zealand Journal of Marine and Freshwater Research 38:481-501.

Long, Z. T. \& P. J. Morin, 2005. Effects of organism size and community composition on ecosystem functioning. Ecology Letters 8:1271-1282.

Marr, S. M., N. D. Impson \& D. Tweddle, 2012. An assessment of a proposal to eradicate non-native fish from priority rivers in the Cape Floristic Region, South Africa. African Journal of Aquatic Science 37:131142.

Marr, S. M., M. P. Marchetti, J. D. Olden, D. L. Morgan, E. García-Berthou, I. Arismendi, J. A. Day, C. L. Griffiths \& P. H. Skelton, 2010. Freshwater fish introductions in mediterranean-climate regions: are there commonalities in the conservation problem? Diversity and Distributions 16:606-619.

McKinney, M. L. \& J. L. Lockwood, 1999. Biotic homogenization: a few winners replacing many losers in the next mass extinction. TREE 14:450-453.

Millennium Ecosystem Assessment, 2005. Ecosystem and Human Well-being: Biodiversity Synthesis. World Resources Institute, Washington, DC.

Morgan, D. L., H. S. Gill, M. G. Maddern \& S. J. Beatty, 2004. Distribution and impacts of introduced freshwater fishes in Western Australia. New Zealand Journal of Marine and Freshwater Research 38:511523. 
Morgan, D. L., D. C. Thorburn \& H. S. Gill, 2003. Salinization of south-western Western Australian rivers and the implications for the inland fish fauna - the Blackwood River, a case study. Pacific Conservation Biology 9:161-171.

Moyle, P. B., 1976. Fish introductions in California: history and impact on native fishes. Biological Conservation 9:101-118.

Moyle, P. B., 1995. Conservation of native freshwater fishes in the Mediterranean-type climate of California, USA: a review. Biological Conservation 72:271-279.

Moyle, P. B., J. V. E. Katz \& R. M. Quiñones, 2011. Rapid decline of California's native inland fishes: A status assessment. Biological Conservation 144:2414-2423.

Moyle, P. B. \& M. P. Marchetti, 2006. Predicting invasion success: freshwater fishes in California as a model. BioScience 56:513-524.

Olden, J. D., 2006. Biotic homogenization: a new research agenda for conservation biology. Journal of Biogeography 33:2027-2039.

Olden, J. D., M. J. Kennard, F. Leprieur, P. A. Tedesco, K. O. Winemiller \& E. García-Berthou, 2010. Conservation biogeography of freshwater fishes: recent progress and future challenges. Diversity and Distributions 16:496-513.

Olden, J. D., M. J. Kennard \& B. J. Pusey, 2008. Species invasion and the changing biogeography of Australian freshwater fishes. Global Ecology and Biogeography 17:25-37.

Olden, J. D., J. L. Lockwood \& C. L. Parr, 2011. Species invasions and the biotic homogenization of faunas and floras. In Whittaker, R. J. \& R. J. Ladle (eds), Conservation Biogeography. Wiley-Blackwell, Oxford:224-243.

Olden, J. D. \& T. P. Rooney, 2006. On defining and quantifying biotic homogenization. Global Ecology and Biogeography 15:113-120.

Pauchard, A., L. A. Cavieres \& R. O. Bustamante, 2004. Comparing alien plant invasions among regions with similar climates: where to from here? Diversity and Distributions 10:371-375.

Pool, T. K. \& J. D. Olden, 2012. Taxonomic and functional homogenization of an endemic desert fish fauna. Diversity and Distributions 18:366-376.

Rahel, F. J., 2004. Unauthorized fish introductions: Fisheries management of the people, for the people, or by the people? In Nickum, M. J., P. M. Mazik, J. G. Nickum \& D. D. MacKinlay (eds), Propagated fishes in resource management American Fisheries Society Symposium Series 44. American Fisheries Society, Bethesda, MD: 431-443. 
Shumka, S., L. Shuka \& S. Mali, 2010. Rivers water life and the responses of possible hydropower's to be constructed in the water courses of Vjosa, Semani and Drini in Albania. BALWOIS 2010 25:1-8.

Soto, D., I. Arismendi, J. González, J. Sanzana, F. Jara, C. Jara, E. Guzmán \& A. Lara, 2006. Southern Chile, trout and salmon country: invasion patterns and threats for native species. Revista Chilena de Historia Natural 79:97-117.

Soto, D., F. Jara \& C. Monero, 2001. Escaped salmon in the inner seas, Southern Chile: facing ecological and social conflicts. Ecological Applications 11:1750-1762.

Tedesco, P. A., F. Leprieur B. Hugueny, S. Brosse, H, H. Dürr, O. Beauchard, F. Busson, \& T. Oberdorff, 2012. Patterns and processes of global freshwater fish endemism. Global Ecology and Biogeography 21:977987.

Villéger, S., S. Blanchet, O. Beauchard, T. Oberdorff \& S. Brosse, 2011. Homogenization patterns of the world's freshwater fish faunas. Proceedings of the National Academy of Sciences 108:18003-18008.

Vitule, J. R. S., F. Skóra \& V. Abilhoa, 2012. Homogenization of freshwater fish faunas after the elimination of a natural barrier by a dam in Neotropics. Diversity and Distributions 18:111-120.

Woodward, G., B. Ebenman, M. Emmerson, J. M. Montoya, J. M. Olesen, A. Valido \& P. H. Warren, 2005. Body size in ecological networks. TREE 20:402-409.

Zenetos, A., M.-A. Pancucci-Papadopoulou, S. Zogaris, E. Papastergiadou, L. Vardakas, K. Aligizaki \& A. N. Economou, 2009. Aquatic alien species in Greece (2009): tracking sources, patterns and effects on the ecosystem. Journal of Biological Research-Thessaloniki 12:135-172. 
Fig. 1 Non-metric multidimensional scaling summarising a) taxonomic and b) functional changes in fish composition between the historical $(\boldsymbol{\Delta})$ and present-day $(\Delta)$ assemblages in Mediterraneanclimate regions. Convergence of region position in multivariate space provides evidence for taxonomic homogenization over time. See Table 1 for region codes.

Fig. 2 Box and whisker plots summarising the catchment-level changes in taxonomic $(\Delta T S)$ and functional $(\triangle F S)$ compositional similarity between the present day and historical freshwater fish assemblages in the northern Mediterranean Basin, California, Chile, south-western Australia and the south-western Cape. Each box corresponds to 25th and 75th percentiles; the dark line inside each box represents the median; error bars show the minima and maxima except for outliers (open circles, corresponding to values $>1.5$ box-heights from the box). See Table 1 for region codes.

Fig. 3 Bar plots summarising the changes in functional trait composition of the freshwater fish assemblages over all med-regions (\%) included in this study. The white bars represent the historical fish assemblage, the grey bars the present day fish assemblages, and the black bars represent the introduced fish assemblage. The trait codes are adult trophic status ( $\operatorname{Tr} 1$ - planktivore; $\operatorname{Tr} 2$ - herbivore and detritivore; $\operatorname{Tr} 3$ - invertivore; $\operatorname{Tr} 4$ - omnivore; $\operatorname{Tr} 5$ - piscivore); degree of parental care (PC1 - no parental care; PC2 - brood hiders; PC3 - guarders; PC4 - bearers); population doubling time (PD1 - < 15 months; PD2 - 1.4-4.4 years; PD3 - 4.4-14 years; PD4 - > 14 years); maximum adult size (S1 - < $10 \mathrm{~cm} ; \mathrm{S} 2$ - 11- $20 \mathrm{~cm} ; \mathrm{S} 3-21-40 \mathrm{~cm} ; \mathrm{S} 4-41-80 \mathrm{~cm} ; \mathrm{S} 5-81-160 \mathrm{~cm} ; \mathrm{S} 6$ - >160 cm standard length); physiological tolerance (Tol1 - intolerant fishes; Tol2 - moderately tolerant fishes; Tol3 tolerant fishes; Tol4 - extremely tolerant fishes); and extent of migration (Mig0 - non-migratory, Mig1 - potamadromous, Mig2 - diadromous, Mig3 - amphidromous). 
Fig. Ia Taxonomic homogenization

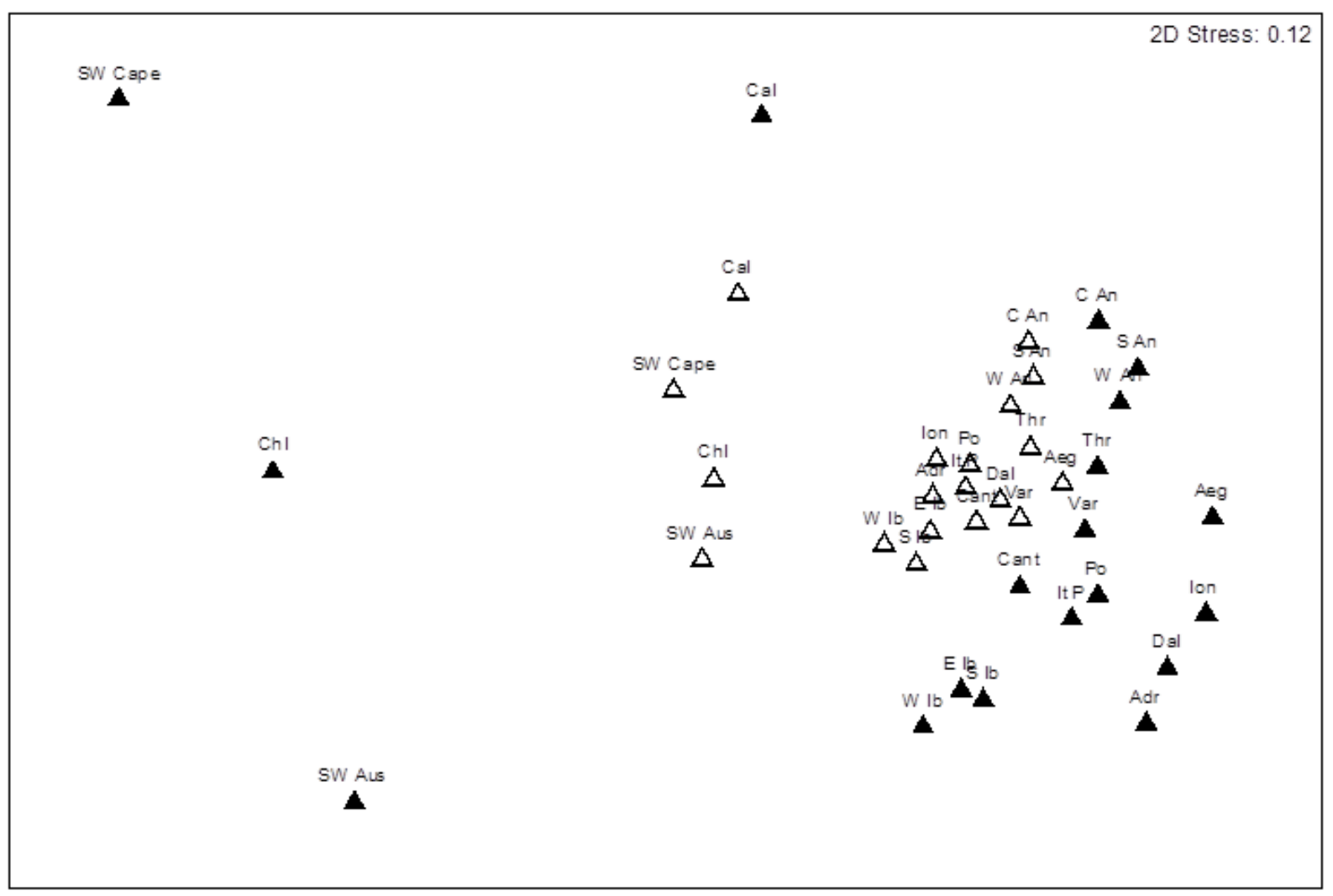

Fig. Ib Functional homogenization

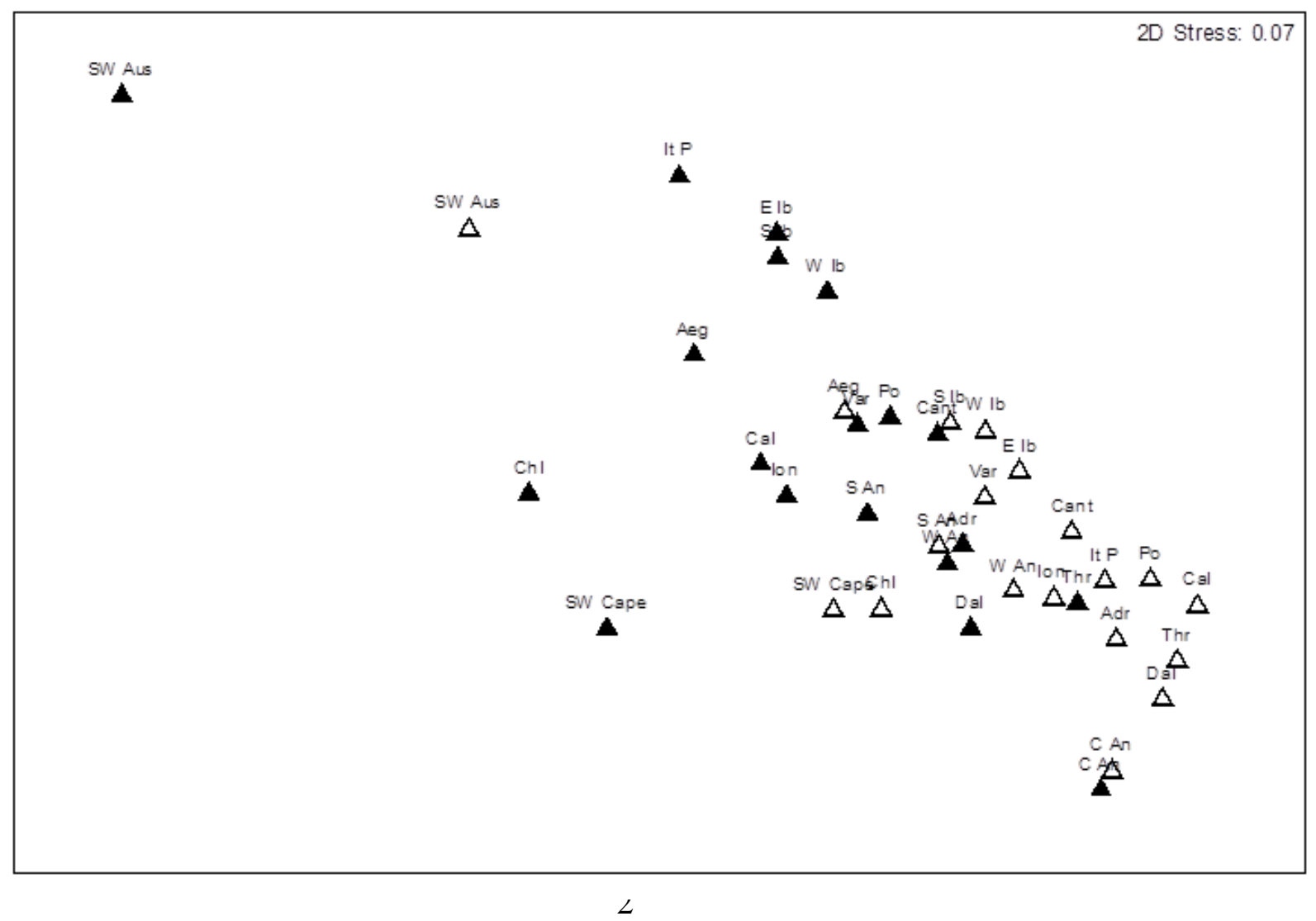


Taxonomic

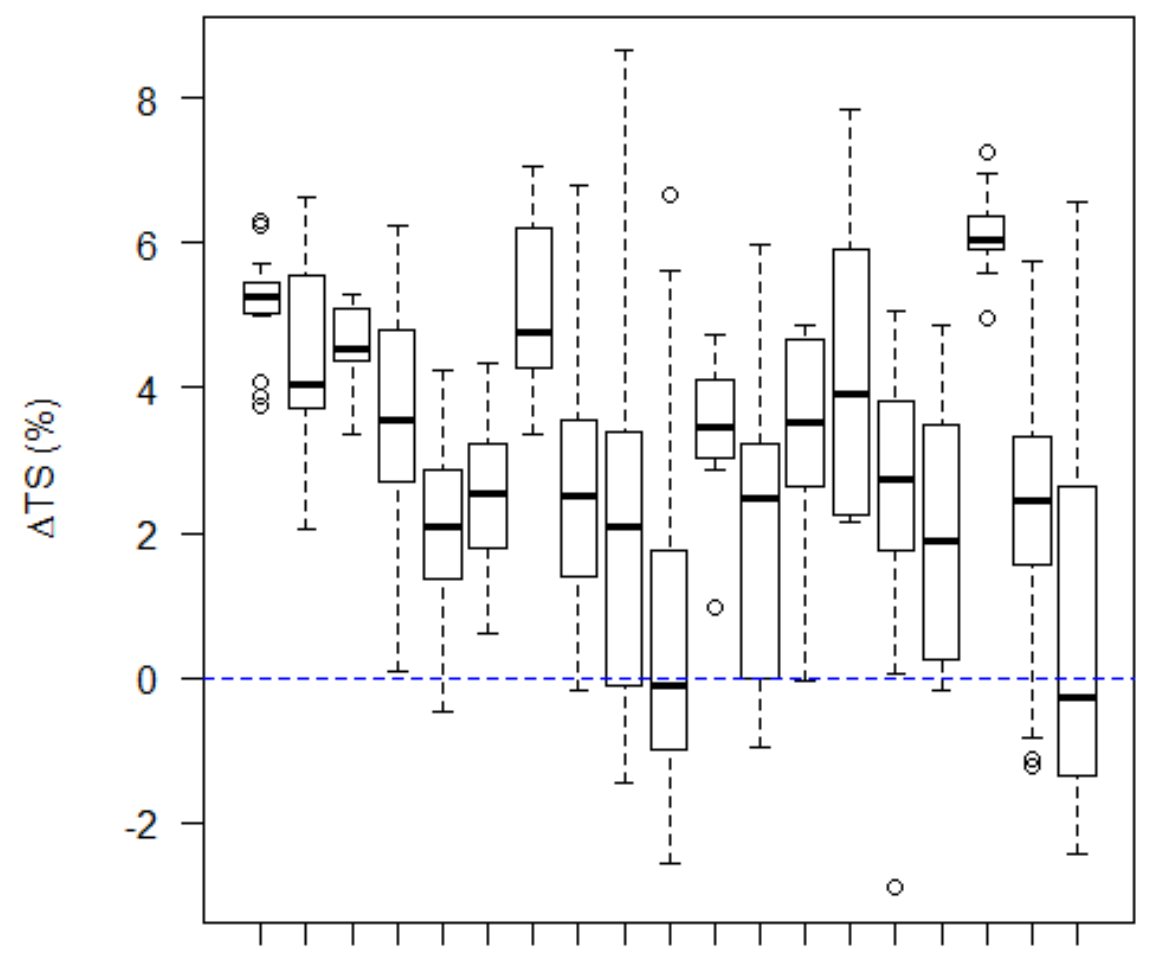

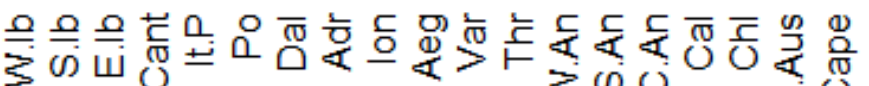

क
Functional

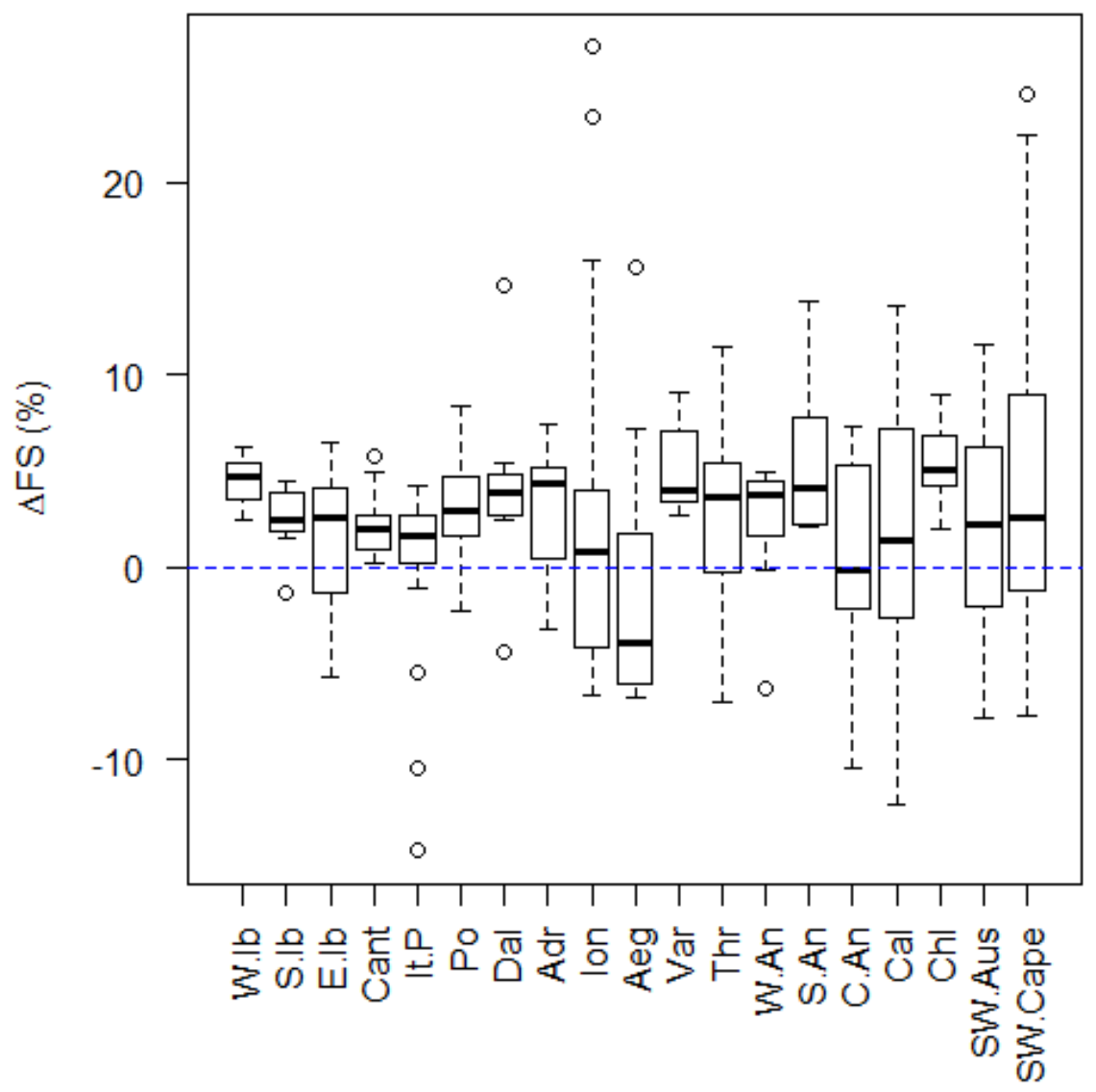


Fig. 3.

Trophic Level

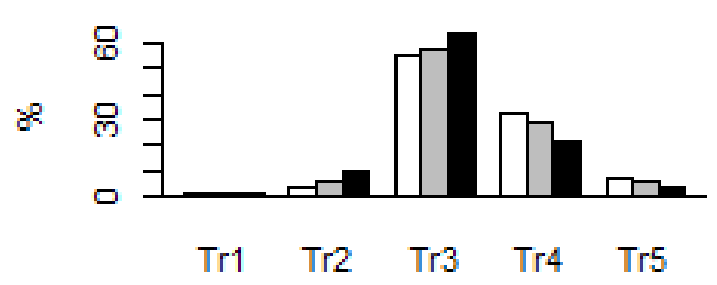

Population Doubling Time

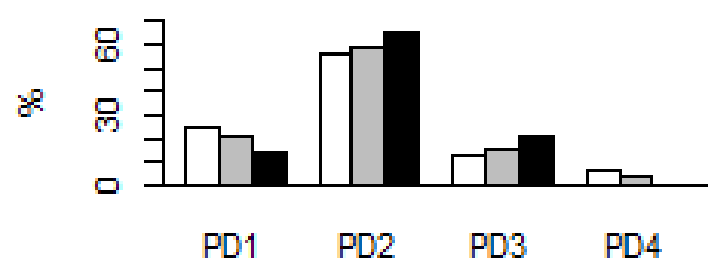

Physiological Tolerance

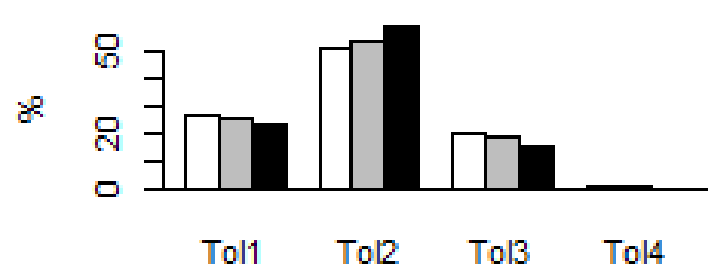

Parental Care

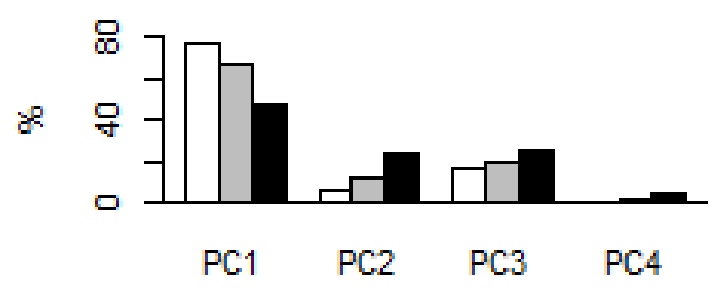

Adult Size

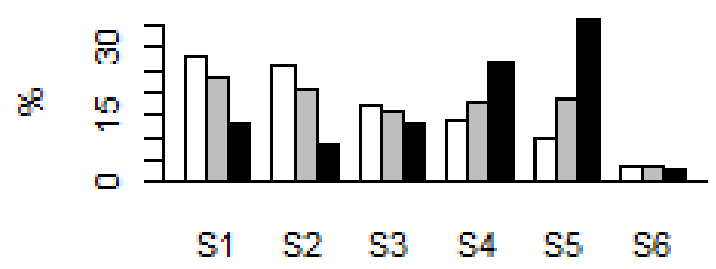

Extent of Migration

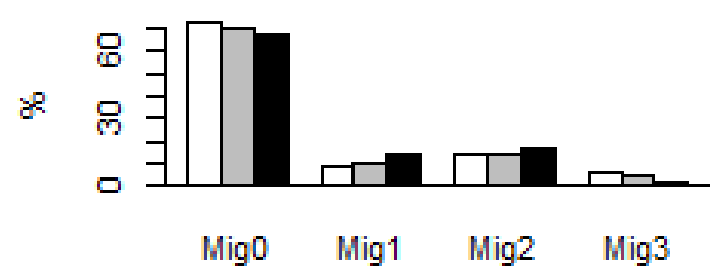


Table 1 Fish richness and biotic homogenization in med-regions. Reported statistics include the number of freshwater fish species that are native $(N)$, extirpated $(X)$, translocated within the region $(T)$, and introduced or exotic (excluding translocated) to the region $(I)$; the pairwise taxonomic similarity between historical and present-day communities $(T S)$, the average historical pairwise taxonomic similarity $\left(T S_{H}\right)$, the average change in pairwise taxonomic similarity $(\Delta T S)$; the pairwise functional similarity between historical and present-day communities $(F S)$, the average historical pairwise functional similarity $\left(F S_{H}\right)$, and the average change in pairwise functional similarity $(\triangle F S)$ between the historical and present-day fish faunas.

\begin{tabular}{|c|c|c|c|c|c|c|c|c|c|c|c|}
\hline & \multirow[t]{2}{*}{$\begin{array}{l}\text { Region } \\
\text { codes }\end{array}$} & \multicolumn{4}{|c|}{ No. species } & \multicolumn{3}{|c|}{$\begin{array}{c}\text { Taxonomic similarity } \\
\qquad(\%)\end{array}$} & \multicolumn{3}{|c|}{$\begin{array}{l}\text { Functional similarity } \\
\qquad \%)\end{array}$} \\
\hline & & $N$ & $X$ & $T$ & $I$ & $T S$ & $T S_{H}$ & $\Delta T S$ & $F S$ & $F S_{H}$ & $\triangle F S$ \\
\hline All regions & & 482 & 11 & 46 & 136 & & 6.83 & 7.47 & & 68.69 & 6.80 \\
\hline Northern Mediterranean & & 374 & 8 & 33 & 88 & & 8.63 & 7.80 & & 71.83 & 6.65 \\
\hline California, Chile, sw Aus, sw Cape & & 108 & 3 & 14 & 68 & & 0.08 & 6.24 & & 61.68 & 7.39 \\
\hline Western Iberia & $\mathrm{W} \mathrm{Ib}$ & 31 & 1 & 2 & 15 & 65.22 & 7.91 & 8.24 & 80.70 & 73.96 & 3.96 \\
\hline Southern Iberia & $\mathrm{S} \mathrm{Ib}$ & 28 & 2 & 2 & 17 & 57.78 & 9.46 & 7.09 & 77.00 & 71.71 & 5.14 \\
\hline Eastern Iberia & $\mathrm{E} \mathrm{Ib}$ & 27 & 1 & 5 & 24 & 50.98 & 9.84 & 10.35 & 69.26 & 71.01 & 9.25 \\
\hline Cantabric Coast-Languedoc & Cant & 48 & 2 & 10 & 22 & 65.71 & 11.44 & 9.27 & 82.47 & 73.57 & 7.07 \\
\hline Italian Peninsula & It $\mathrm{P}$ & 23 & 1 & $*$ & 45 & 32.35 & 10.47 & 9.47 & 51.11 & 67.45 & 14.03 \\
\hline Gulf of Venice (Po drainages) & Po & 39 & 2 & $*$ & 34 & 50.68 & 10.70 & 10.21 & 70.91 & 76.55 & 3.15 \\
\hline Dalmatian coast & Dal & 58 & 2 & 1 & 27 & 65.88 & 6.71 & 10.39 & 81.32 & 70.02 & 6.76 \\
\hline South East Adriatic & Adr & 50 & 3 & 6 & 28 & 60.26 & 5.84 & 8.60 & 80.00 & 74.43 & 5.45 \\
\hline Ionian drainages & Ion & 39 & 1 & 9 & 26 & 58.46 & 7.28 & 8.90 & 75.73 & 76.35 & 5.36 \\
\hline Aegean drainages & Aeg & 29 & 0 & 0 & 10 & 74.36 & 7.18 & 4.62 & 85.29 & 71.48 & 1.20 \\
\hline Vardar & Var & 38 & 0 & 4 & 12 & 76.00 & 11.03 & 6.48 & 86.36 & 76.44 & 3.72 \\
\hline Thrace & Thr & 66 & 0 & 7 & 17 & 79.52 & 10.83 & 6.65 & 88.59 & 68.04 & 9.02 \\
\hline Western Anatolia & W An & 53 & 0 & 0 & 9 & 85.48 & 8.10 & 5.96 & 92.17 & 73.78 & 7.47 \\
\hline Southern Anatolia & S An & 45 & 0 & 0 & 7 & 86.54 & 6.53 & 5.34 & 92.78 & 74.05 & 4.48 \\
\hline Central Anatolia & C An & 81 & 3 & 0 & 8 & 86.52 & 6.16 & 5.45 & 97.36 & 58.18 & 13.66 \\
\hline California & $\mathrm{Cal}$ & 38 & 3 & 12 & 44 & 42.68 & 0.00 & 5.53 & 64.96 & 72.12 & 2.56 \\
\hline Chile & Chl & 28 & 0 & 0 & 23 & 54.90 & 0.15 & 7.65 & 70.89 & 66.55 & 9.65 \\
\hline SW Australia & SW Aus & 10 & 0 & 0 & 10 & 50.00 & 0.15 & 6.53 & 66.67 & 39.89 & 9.68 \\
\hline SW Cape & SW Cape & 33 & 0 & 2 & 16 & 67.35 & 0.00 & 5.25 & 80.49 & 68.16 & 7.66 \\
\hline
\end{tabular}

\footnotetext{
Note

* levels of translocation in the Italian regions could not be calculated from the available data.
} 
1 Table 2 Summary of the 20 freshwater fishes most widely introduced in the 19 med-regions studied. The proportion of catchments by region occupied by the 2 species is given (blank entries $=$ species has not been introduced) ordered by level of introduction. See Table 1 for region codes.

\begin{tabular}{|c|c|c|c|c|c|c|c|c|c|c|c|c|c|c|c|c|c|c|c|}
\hline Species & W Ib & $\mathrm{S} \mathrm{Ib}$ & $\mathrm{E} \mathrm{Ib}$ & Cant & It $\mathrm{P}$ & Po & Dal & Adr & Ion & Aeg & Var & Thr & W An & S An & C An & $\mathrm{Cal}$ & Chl & $\begin{array}{l}\text { SW } \\
\text { Aus }\end{array}$ & $\begin{array}{l}\text { SW } \\
\text { Cape }\end{array}$ \\
\hline Gambusia holbrooki & 0.90 & 1.00 & 0.71 & 0.50 & 0.39 & 0.42 & 1.00 & 1.00 & 0.58 & 0.32 & 0.71 & 0.61 & 0.75 & 1.00 & 0.50 & & 0.92 & 0.76 & \\
\hline Cyprinus carpio & 1.00 & 0.88 & 1.00 & 0.85 & 0.87 & 0.75 & 0.88 & 0.89 & 0.42 & 0.12 & 0.14 & & & & & 0.47 & 1.00 & 0.09 & 0.35 \\
\hline Oncorhynchus mykiss & 0.45 & 0.38 & 0.71 & 0.85 & 0.39 & 0.58 & 0.75 & 0.67 & 0.29 & 0.12 & 0.57 & 0.22 & 0.25 & 0.67 & 0.56 & & 1.00 & 0.30 & 0.33 \\
\hline Carassius auratus & 1.00 & 0.75 & 1.00 & 0.35 & 0.87 & 0.83 & 0.25 & 0.33 & 0.05 & & & 0.09 & 0.08 & & 0.11 & 0.38 & 0.77 & 0.30 & 0.15 \\
\hline Lepomis gibbosus & 0.75 & 0.75 & 0.43 & 0.65 & 0.65 & 0.50 & 1.00 & 0.22 & 0.05 & & 0.57 & 0.22 & 0.25 & 0.17 & & 0.09 & & & \\
\hline Salmo trutta & 0.35 & 0.13 & 0.29 & 0.25 & 1.00 & 1.00 & 0.50 & & 0.03 & & 0.14 & & & & & 0.31 & 1.00 & 0.06 & 0.17 \\
\hline Carassius gibelio & & & & 0.40 & & & 0.88 & 0.44 & 0.18 & 0.08 & 0.86 & 0.57 & 0.50 & 0.50 & 0.33 & & & & \\
\hline Micropterus salmoides & 0.75 & 0.88 & 0.43 & 0.10 & 0.35 & 0.33 & 0.13 & & 0.03 & & & & & & & 0.59 & & & 0.54 \\
\hline Pseudorasbora parva & & & 0.29 & 0.30 & 0.43 & 0.75 & 0.38 & 0.78 & 0.05 & & 0.43 & 0.22 & 0.17 & 0.17 & 0.11 & & & & \\
\hline Esox lucius & 0.15 & 1.00 & 0.71 & 0.15 & 0.04 & & 0.50 & 0.11 & & & 0.14 & 0.04 & & & & & & & \\
\hline Sander lucioperca & 0.10 & 0.13 & 0.43 & 0.45 & 0.13 & 0.33 & 0.25 & 0.11 & & & & 0.04 & 0.33 & & 0.28 & & & & \\
\hline Gobio lozanoi & 1.00 & 0.75 & 0.71 & & & & & & & & & & & & & & & & \\
\hline Tinca tinca & & 0.13 & & & & & 0.88 & 0.22 & 0.16 & & 0.14 & & & & & & 0.69 & & 0.02 \\
\hline Ameiurus melas & 0.50 & 0.25 & 0.14 & 0.25 & 0.26 & 0.50 & 0.13 & 0.11 & & & & & & & & 0.31 & 0.15 & & \\
\hline Ctenopharyngodon idella & & & & & 0.09 & 0.08 & 0.25 & 0.33 & 0.16 & 0.08 & 0.29 & 0.04 & & & & & 0.38 & & \\
\hline Silurus glanis & 0.50 & & 0.29 & 0.35 & 0.13 & 0.42 & 0.25 & 0.11 & 0.08 & & & & & & & & & & \\
\hline Gambusia affinis & & & & & & & & & & & & & & & & 0.50 & 0.92 & & 0.23 \\
\hline Salvelinus fontinalis & 0.50 & & 0.29 & & 0.04 & 0.08 & 0.13 & 0.11 & 0.03 & & 0.14 & 0.04 & & & & 0.16 & 0.54 & & \\
\hline Perca fluviatilis & & & 0.29 & 0.40 & 0.09 & & 0.25 & 0.11 & 0.05 & & 0.14 & & & & & & & 0.27 & \\
\hline Carassius carassius & & & & 0.60 & 0.13 & 0.08 & 0.25 & & & & & 0.09 & & & 0.11 & & & & \\
\hline
\end{tabular}

3 
attachment to manuscript
Click here to download attachment to manuscript: Marr et al_Fishlnvasions_TABLE-S1_edited final.docx Click here to down aad attachmento manuscript: Marr et al_Fishinvasions TABLE-S1_edited finaldocx (n) (1) (1) (1) .

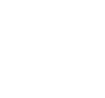

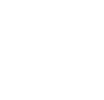
(1) (1)

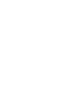

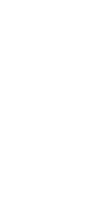
. (n)

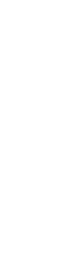

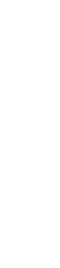

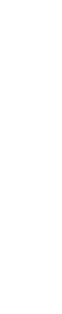

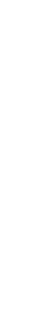

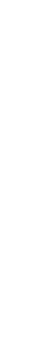
列 . 
attachment to manuscript
Click here to download attachment to manuscript: Marr et al_Fishlnvasions_TABLE-S2_edited final.docx

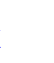

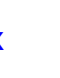

